\title{
レーザー解説
}

$$
\text { ベンゼンのレーザーフォトリシス }
$$

（1981年 4 月 15日 受理）

\section{Laser Photolysis of Benzene}

\author{
Nobuaki NAKASHIMA
}

(Recieved April 15, 1981)

\section{1.はじめに}

分子と光の相互作用や光反応初期過程の研究 は太陽エネルギー利用, 光生物反応, 有用な物 質の合成等の基礎として重要である。ナノ，ピ コ秒レーザーによるフラッシュフオトリシス法 は有機化合物の光反応を含む励起状態の動的挙 動に対し最も直接的で重要な情報を与える”。多 くの有機化合物の中でベンゼンは最も基本的有 機化合物の一つであり，従つて常に新しい技術 で詳しく調べられて来た。2-7)レーザーの出現によ り1960年代の後半からいくつかの問題が解決さ れた。ことに最近強力紫外レーザー（エキシマ ーレーザー，Ndレーザーの 4 倍波）が用いら れるようになり更にいくつかの重要な問題が解 決された。

本稿ではナノ秒レーザーフォトリシス法につ いて紹介すると共に，ベンゼン光化学に関する 代表的問題とその解決について, 現状を述べる ことにしたい。

\section{2.レーザーフォトリシス ${ }^{11}$}

一般に有機分子の蛍光輻射寿命は 1 数百ナ ノ秒であるから，それらの状態の研究や光化学 反応を調べるにはナノ，ピコ秒の時間領域での
研究が重要となる。基本的な測定量としては蛍 光の時間変化及び中間体の吸収スペクトルとの 時間変化がある。しかし, 反応生成物が励起状 態でその発光が観測できる系は少ない。従って, 後者の吸収スペクトルを測定する方が， S/N が良くないけれども情報量が多い。

1960年代の後半にQスイッチレーザーの出現 によりナノ秒レーザーフォトリシスが可能とな り，70年代の前半にピコ秒レーザーフォトリシ ス法が可能となった。最近使われている紫外線 レーザーを表 1 に紹介する。

実験には例えばエキシマーレーザー248nm の 場合は $50 \mathrm{~mJ} / \mathrm{cm}^{2}$ 程度の光量が必要となる。 1 $\mathrm{cm}^{3}$ に吸収されたとすると平均励起分子濃度は $1 \times 10^{-4} \mathrm{M}$ となる。分子吸光係数が $10^{4}$ 程度の 許容遷移であればモニター光は $90 \%$ 吸収される ことになる。要するにかなりの高出力のレーザ 一が必要な実験である。

基本的分子であるべンゼンについてはピコ秒 レーザーフォトリシスによる研究はまだほとん どない ${ }^{23)}$ 。その理由の一つはベンゼンを励起す る為には260nm 以下の紫外光が必要であるにも がわらず，強力なピコ秒パルスは容易に得ら れないことである。

ナノ秒レーザーフォトリシスの光学系をFig. 
Table. 1. ns $\sim$ ps Lasr photolysis

\begin{tabular}{ccccc} 
Laser & Wavelength/nm & Pulsewidth/ns & Output/m J & Example \\
\hline Ruby (ps) & 347 & 0.03 & 5 & exciplex $^{1)}$ \\
YAG (ps) & 266,355 & 0.015 & $2(4 \omega), 5(3 \omega)$ & stilbene $^{1)}$ \\
Ar-Dye & 307 & 0.0005 & 0.1 & stilbene $^{1)}$ \\
YAG(ns) & 266 & 5 & $50(4 \omega)$ & benzene $^{9 /}$ \\
Excimer & $157,193,248$ & 15 & $200(\mathrm{KrF})$ & benzene $^{8,11)}$ \\
\hline
\end{tabular}

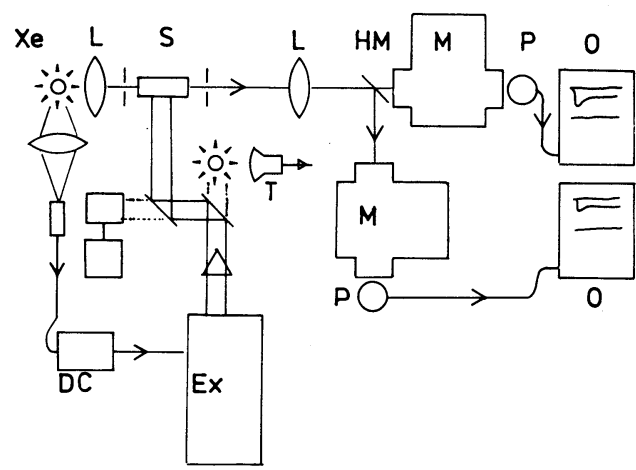

Fig. 1. Schematic diagram of ns laser photolysis. Xe: pulsed Xe lamp, L: lens, S: sample, HM: half mirror, M: monochromator, T: trigger, DC: delay circuit, and Ex: excimer laser.

1 に示した。これは気相ベンゼンのフォトリシ スに用いた光学系である。エキシマレーザー $(\mathrm{KrF})$ を励起光源としスペクトルランプは同 期したXeフラッシュランプである。2 台の分 光器を用いるがその内一台はスペクトルを規格 化する為に利用している ${ }^{8)}$ 。その他, 最近では $\mathrm{S} / \mathrm{N}$ を 1 発の信号で $1 \%$ 変動が議論できる まで高めたり"，コンピュータ付オシロスコー プでデータ処理の信頼性を向上させたシステム 等が発表されている ${ }^{10 !} 。$ ○チチャンネル（波長, 時間について）システムの導入は今後の課題で あろう。

\section{3. ベンゼンの励起状態}

ベンゼンの $3 つ の$ 電子状態 $\left({ }^{1} \mathrm{~B}_{2 u}: 4.7 \mathrm{eV}\right.$, ${ }^{1} \mathrm{~B}_{1 u} ： 6.2 \mathrm{eV},{ }^{1} \mathrm{E}_{1 u}: 6.9 \mathrm{eV}$ ) は基低状態からの 吸収スペクトル等で詳しく研究され, 確定して いた。 4 つ目の $\pi$ ー $\pi^{*}$ 電子励起状態とされる $1{ }^{1} \mathrm{E}_{28}$ 状態は Hückel の分子軌道でも $\mathrm{a}_{2 u} \rightarrow \mathrm{e}_{2 u}$ 遷移として予想されている。しかし，そのエネ

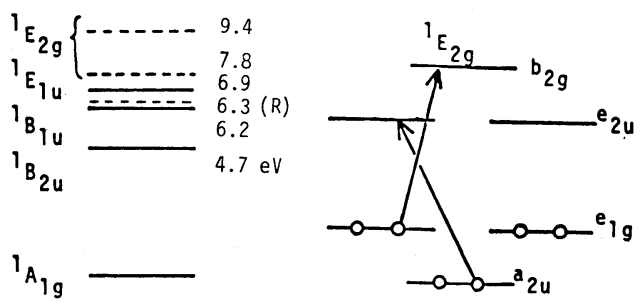

Fig. 2. a) Energy diagram of benzene. Dotted lines are determined by laser spectroscopies b) Hückel molecular orbital of benzene.

ルギー位置等に関し，明確な実験的証明がなか つた。種々の測定の試みにもかかわらず $1 / 4$ 世紀以上にわたって不明で, 最近では“elusive” (つかまえどごろのない) ${ }^{1} \mathrm{E}_{2 \boldsymbol{g}}$ 状態と呼ばれて いた。“g”状態であるから基底状態から禁制 従って 2 光子許容の遷移であり, 当初から Fig. 2 (b) に示すような 2 電子励起的性格であるこ とが理論的にも予想されていた。従って, 最低 励起一重項状態 $\left({ }^{1} \mathrm{~B}_{2 u}\right)$ からの吸収スペクトル を測定すればその位置が明らかにできるものと 期待される。エキサイマーレーザー $(\mathrm{KrF})$ に 叔秒レーザーフォトリシスにより $1{ }^{1} \mathrm{E}_{28}$ のみならず $2{ }^{1} \mathrm{E}_{28}$ も明らかにされた ${ }^{8111}$ 。

ベンゼンの励起状態からの吸収スペクトルの 測定は’60年代の終りの頃 Thomas や JoussotDubienらにより試みられた。しかし, 彼らの 実験では濃度が高かった為エキサイマー（励起 二量体：(BB)*) からの吸収スペクトルを見て いた。ベンゼンの濃度が高いと $500 \mathrm{~nm}$ 付近にエ キサイマーによる吸収 $\left({ }^{1} \mathrm{E}_{1 u} \leftarrow{ }^{1} \mathrm{~B}_{18}\right)$ が見文る。

Fig. 3 に示すよjに，低濃度で測定することに よりベゼンモノマーによるスペクトルが得られ 


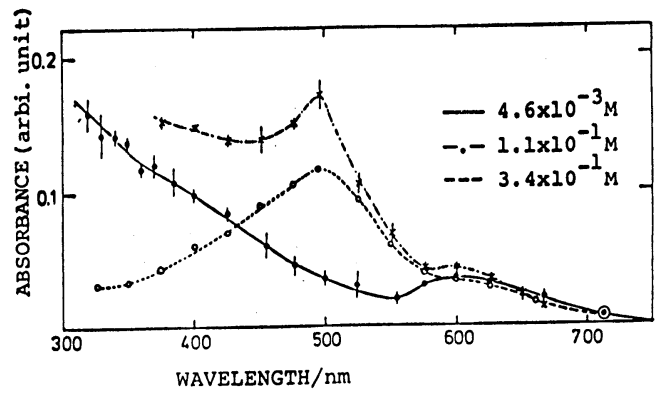

Fig. 3. Concention dependence of trasient spectra.

た。全波長領域についての結果を Fig 4, 5 に示す。計算で予測される $2 つ{ }^{1} \mathrm{E}_{28}$ の位置及 び既に知られている ${ }^{1} \mathrm{E}_{1 u}$ を Fig. 4 の下に示し た。 $25000 \mathrm{~cm}^{-1}$ 付近の肩又はピークを $1{ }^{1} \mathrm{E}_{2 g}$, $37000 \mathrm{~cm}^{-1}$ を $2{ }^{1} \mathrm{E}_{2 \mathrm{~g}}, \quad 17000 \mathrm{~cm}^{-1}$ のピークは振電 相互作用によって許される ${ }^{1} \mathrm{E}_{1 u} \leftarrow{ }^{1} \mathrm{~B}_{2 u}$ と帰属で きる。

最近 3 光子イオン化法で ${ }^{1} \mathrm{E}_{18}$ リドベルグ状態

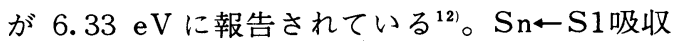
スペクトルでは ${ }^{1} \mathrm{E}_{18} \leftarrow{ }^{1} \mathrm{~B}_{2 u}$ の遷移は見られな かった。その理由は多光子イオン化では ${ }^{1} \mathrm{~A}_{\boldsymbol{g}} \rightarrow$ ${ }^{1} \mathrm{E}_{1 u} \rightarrow{ }^{1} \mathrm{E}_{18} \rightarrow$ イオン化の 3 光子過程と考えられ るから ${ }^{1} \mathrm{E}_{1 u} \rightarrow{ }^{1} \mathrm{E}_{18} \rightarrow$ イオン化の効率が $\mathrm{E}_{18} \leftarrow$ ${ }^{1} \mathrm{~B}_{2 u}$ に比較して大きいためと考えられる。

${ }^{1} \mathrm{E}_{18}$ を確定する目的の 2 光子吸収の実験が多 数行なわれている。しかし，それらの研究は基 底状態 $\left({ }^{1} \mathrm{~A}_{18}, \mathrm{~S}_{\text {。 }}\right)$ から $7.4 \mathrm{eV}$ まででここで測定 された $1{ }^{1} \mathrm{E}_{2 g}(7.8 \mathrm{eV})$ に達していない。 ${ }^{1} \mathrm{~B}_{2 u},{ }^{1} \mathrm{~B}_{1 u}$ への 2 光子吸収等を観測しているものと思われ る ${ }^{13)}$ 。

結局レーザーが出現して新しく発見されたべ ンゼンの電子励起状態は $1 \mathrm{E}_{2 g}^{1}, 2 \mathrm{E}_{2 g}^{1}$ の $2 つ の \pi$ - $\pi^{*}$ 及び ${ }^{1} \mathrm{E}_{18}$ のリドベルグ状態である。これらの 実験事実はベンゼンが一つの典型的分子である ために, 光反応の機構, 多光子分光, 理論との 比較等に有用である。

\section{4. 第 3 チャンネル}

縮合多環化合物の最低励起一重項状態では蛍 光収量 $\left(\phi_{f}\right)$ と三重項への項間交差 $\left(\phi_{i s c}\right)$ が

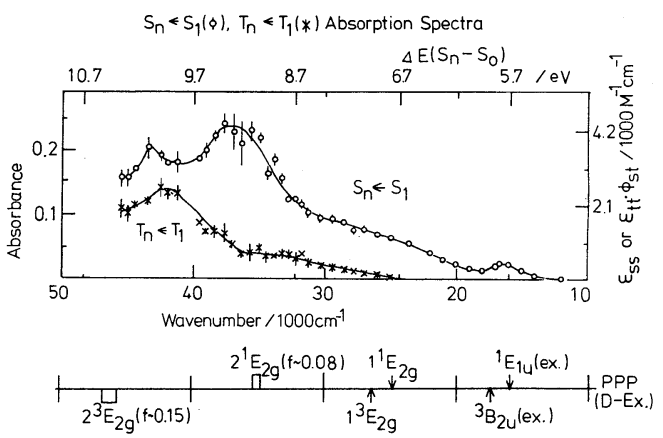

Fig. 4. Time-resolved absorption spectra of benzene in cyclohexane $\left(4.6 \times 10^{-3} \mathrm{M}\right)$ vs monitoring light energy. Upper spectrum $(\phi)$ taken immediately after excitation, corresponds to $\mathrm{S}_{n} \leftarrow \mathrm{S}_{1}$ transition. Lower spectrum $(*)$ taken $160 \mathrm{~ns}$ after excitation, corresponds to $\mathrm{T}_{n} \leftarrow \mathrm{T}_{1}$ transition.

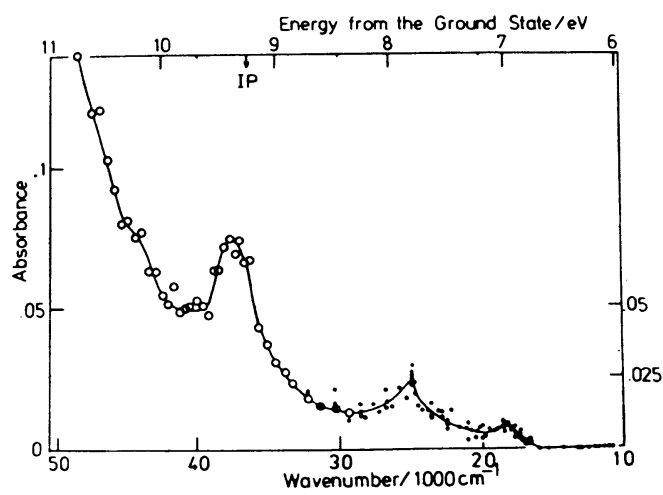

Fig. 5. Transient spectra at the peak of the laser pulse $(t=0)$. At 21 Torr $(O)$ and at 56 Torr (•). These are normalized at $43500 \mathrm{~cm}^{-1}$.

主な過程でそれらの和は $\phi_{f}+\phi_{t s c} \simeq 1$ となる場 合が多い。気相ベンゼンの場合も過剩の振動工 ネルギーがない波長 $\left(266.8 \mathrm{~nm}\right.$ )で励起すると $\phi_{f}$ $=0.22, \phi_{i s c}=0.75$ となり両者の和は 1 に近 いが, 短波長側ではこの和が小さくなり $242 \mathrm{~nm}$ 以下の波長では実際上 0 となる。 $\mathrm{S}_{2}, \mathrm{~S}_{3}$ 励起 ( $\leqq 210 \mathrm{~nm})$ では化学反応の為であることが確 められている。 $\mathrm{S}_{1}$ 励起では反応収率は小さく ベンズバレン (命) が数\%のできるのみであ る。従って, 蛍光, 三重項への項間交差とは異 


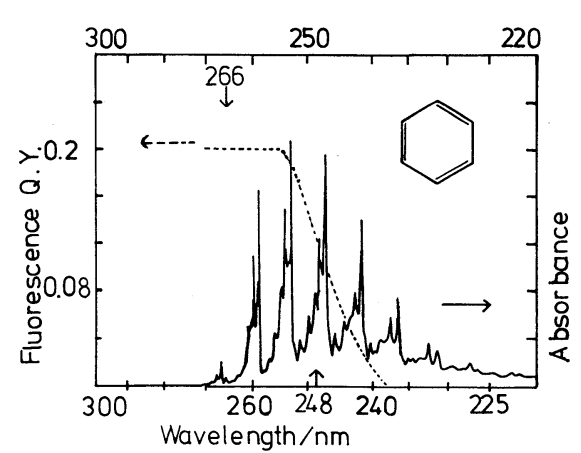

Fig. 6. Absorption spectrum of gaseous benzene and a rough sketch of fluorescence quantum yield.

る第 3 の過程があることになり “第 3 チャンネ ル”と呼ばれている ${ }^{14)} 。$ ベン゙ンの $\mathrm{S}_{1}\left({ }^{1} \mathrm{~B}_{2 u}\right) \leftarrow$ $\mathrm{S}_{0}\left({ }^{1} \mathrm{~A}_{\mathrm{g}}\right)$ の吸収スペクトルと蛍光収量減少の波 長依存性をFig. 6 に示した。この様な現象は ベンゼンに限ったことではなく，トルエン，ア ニリン, ナフタリン等で知られ，一般的に見ら れる。

$\mathrm{KrF} レ$ ザーは248nm であるから100\%第 3 チャンネルの所を励起しているわけではないが, 励起直後の中間体の吸収スペクトルを測定する ことにより何が生成しているかが判断できる。 結果をFig. $7 ， 8$ に示した。結局三重項の吸収 $\left(\mathrm{T}_{n} \leftarrow \mathrm{T}_{1}\right)$ は不明であったが, 試料の温度上昇が 観測された ${ }^{15)}$ 。Fig. 7，8に見られるスペクト ルの時間変化, 次のスキームで表わされる。

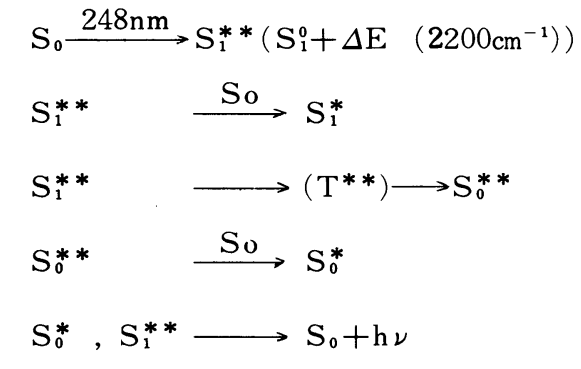

ここで $248 \mathrm{~nm}$ 最低励起一重項より $2200 \mathrm{~cm}^{-1}$ 上に 励起することになる $((1)$ 式)。振動励起されたべ ンゼン $\left(\mathrm{S}_{1}^{* *}\right)$ は基底状態のベンゼン $\left(\mathrm{S}_{0}\right)$ と 衝突してボルツマン分布 $\left(\mathrm{S}_{1}{ }^{*}\right)$ に移行する。 (3)式が第 3 チャンネルを示し, $\mathrm{S}_{1}^{* *}$ はおそら

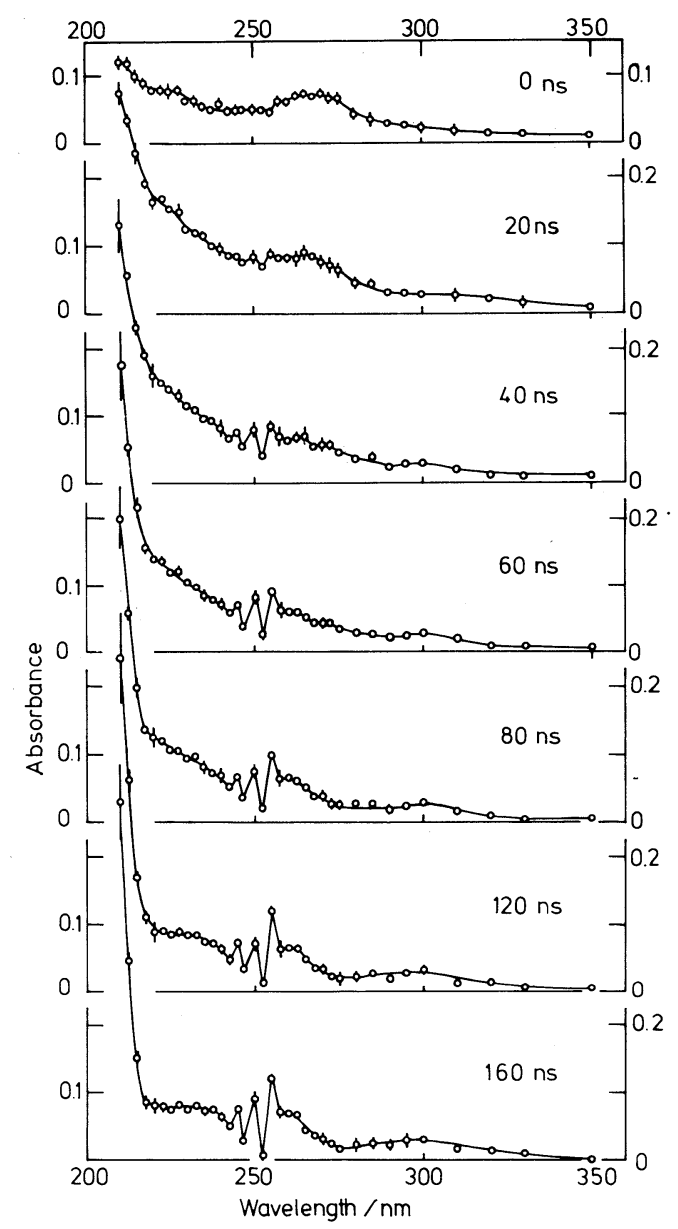

Fig. 7. Time-resolved transient absorption spectra of gaseous benzene at 21 Torr. Delay times are from the peak of the laser pulse.

く寿命の短い三重項を経て基底状態の振動励起 状態 $\left(\mathrm{S}_{0}^{* *}\right)$ となる。 $\mathrm{S}_{0}^{* *}$ は $\mathrm{S}_{0}$ の衝突で熱平衝状 態に達する $\left(\mathrm{S}_{0}^{*}\right)$ 。勿論 $(5)$ 式の様に蛍光を発する 過程もある。Fig. 7,8の $\mathrm{t}=0,10$ ナノ秒のスペク トルは大部分 $\mathrm{Sn}_{\mathrm{n}} \leftarrow \mathrm{S}_{1}$ 吸収を示している。数十 ナノ秒から160ナノ秒では(3), (4)で示される過 程により温度が上昇し複雑な構造が出現する様 子を表わしている。温度上昇により，高い振動 励起状態へも分布することになることが，スペ クトル変化の原因である。これは通常の吸収ス ペクトルでシミュレーションできる。Fì̀. 8 の 一番下の図は高温 $\left(76^{\circ} \mathrm{C}\right)$ のスペクトルから常 


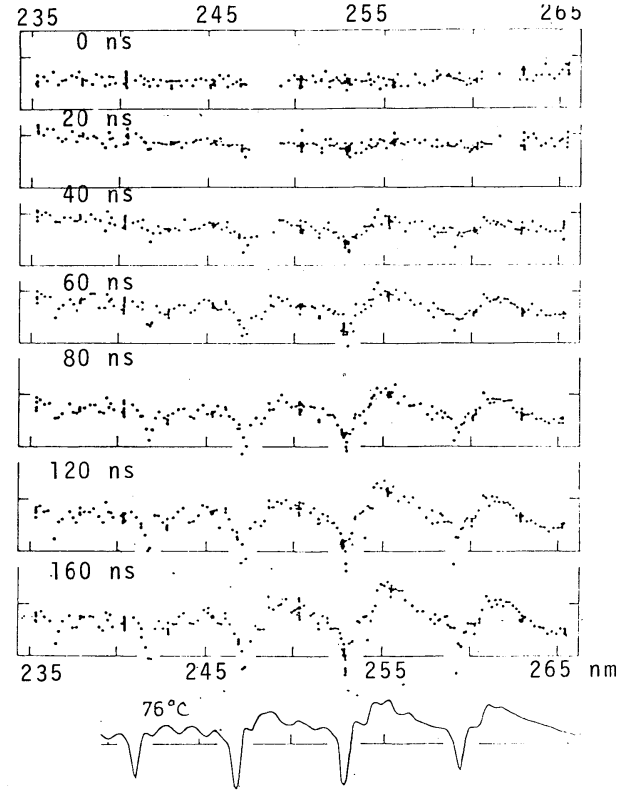

Fig. 8. Time-resolved transient absorptions spectra. Difference $\left(76^{\circ} \mathrm{C}-26^{\circ} \mathrm{C}\right)$ spectrum. Each horizontal line with wavelength markers gives a zero optical density.

温（26ㄷ）のスペクトルを差し引いたものを示 している。定量性に関しては問題があるものの， $160 \mathrm{~ns}$ 後のスペクトルの形をよく説明している。 (3)で三重項を経るこ.とを仮定しているのは酸素 を700Torr 添加しても同様の現象が見られる からである。シスー2ーブテン, $\mathrm{SF}_{6}$ 等の多原 子分子を添加すると添加気体への振動エネルギ 一の移動とベンゼンへの移動が競争になり, 温 度上昇の効果は小さくなった。このように第ゼ ロ次近似の答では, 第 3 チャンネルの行き先は 式(3)で示される様なルートで基底状態の高い振 動励状態ができる過程と思われる。寿命の短い 反応中間体も予想されていたが，スペクトル的 には確認できなかった。第 3 チャンネルの最終 的結論は $242 \mathrm{~nm}$ で励起して $\left(\phi_{f}+\phi_{i s c} \sim 0, \tau_{f}\right.$ 〜 $7 \mathrm{~ns})$ 時間分解能も 1 ナノ秒程度で調べるこ とによって得られるであろう。蛍光寿命の 242 $\mathrm{nm}$ 以下の波長依存性等詳しい実験等を行なう ことにより1970年前半まで盛んに議論された無 輻射遷移の理論との比較検討が可能になると思 われる。
溶液中のベンゼンの無輻射遷移の中味もまだ 未解決である。 $\mathrm{S}_{2}, \mathrm{~S}_{3}$ 励起ではすべてが蛍光状 態に帰ってくるわけではなく $\mathrm{S}_{2} \rightarrow \mathrm{S}_{1}$ は $40 \%$, $\mathrm{S}_{3} \rightarrow \mathrm{S}_{1}$ では70\%が不明である。 $\mathrm{S}_{1}$ に於てもシ クロヘキサン中では $70 \%$, 水溶液中の無放射遷 移は $94 \%$ に達する。20\%はベンズバレンを含む 不安定反応物という説もあり，ナノ，ピコ秒の フラッシュフォトリシスで明らかにすべき問題 と思われる。

\section{4. 三重項状態}

シクロヘキサン等の溶液中では $\mathrm{T}_{n} \leftarrow \mathrm{T}_{1}$ 吸 収 スペクトル (Fig. 3 参照) 及び項間交差の収量 $\left(\phi_{i s c} \simeq 0.25\right)$ 等はすでに求められている。 しかし，気相の三重項に関しては充分明らかに なったとは言えない。水銀ランプを励起光とし たモジュレイション法で $\mathrm{T}_{n} \leftarrow \mathrm{T}_{1}$ スペクトルが 得られているが16) $(231 \mathrm{~nm}, \Delta \lambda 5 \mathrm{~nm})$, 通常の フラッシュフォトリシスではいまだに $\mathrm{T}_{n} \leftarrow \mathrm{T}_{1}$ 吸収スペクトルは得られていない。そこで $\mathrm{KrF}$ レーザーにより $\mathrm{T}_{n} \leftarrow \mathrm{T}_{1}$ 吸収を測定することを 試みた。

$\mathrm{SF}_{6}$ を大量（680torr）に添加した実験では 短い時間内に熱平衡状態に達する。報告されて いる量子収量（ $\phi_{i s c}=0.75$, 溶液中の 3 倍 $)$ を 考慮すると容易に $\mathrm{T}_{n} \leftarrow \mathrm{T}_{1}$ が求められてよいは ずである。しかし，結局 $\mathrm{T}_{n} \leftarrow \mathrm{T}_{1}$ 吸収によるピ ークははっきりしなかった。吸光係数が液相か ら気相へ変わることでかなり弱くなる等のため かも知れない。

気相でのりん光は観測されていないがりん光 寿命の測定に関してはバイアセチルへのエネル ギー移動法により $\frac{1}{\tau_{p}}=5 \times 10^{3} \mathrm{~s}^{-1}+3.6 \times 10^{3}$ $\left[\mathrm{B}_{\text {torr }}\right] \mathrm{s}^{-1}$ が求められている ${ }^{17)}$ 。最近分子線, 2 光子イオン化法を用いて $1.1 \mathrm{eV}$ 振動励起され た Collision-free の三重項の寿命が約 470ns と求められた ${ }^{18)}$ 。励起一重項と同様, 振動励起 された状態の無輻射遷移確率は極めて大きくな ることを示している。

今後, 励起波長を $259 \mathrm{~nm}, 253 \mathrm{~nm}$ と変えて気 
Table II. Photoproducts of benzene

116. $5, \quad 147.0$ polymer (g, major) $\mathrm{HC} \equiv \mathrm{CH}(\mathrm{g}, 8)$<smiles>C=C1C=CC=C1</smiles>

183. $9\left({ }^{1} \mathrm{E}_{1 u}\right)$

$(\mathrm{g}, \sim 50)$,<smiles>C#CC=CC=C</smiles>

$206\left({ }^{1} \mathrm{~B}_{1 u}\right)$

$237-260\left({ }^{1} \mathrm{~B}_{2 u}\right)$
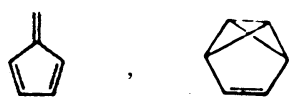

, $(\ell$, ratio $5: 15: 3)$

$(\mathrm{g}, 2-4),(\ell, 2)$

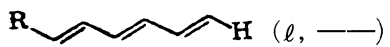

a) g: in gas phase, $\ell$ : in solution, and yield

相のフラッシュフォトリシスを行い, 気相三重項 の性質を明らかにしていく必要がある。

\section{5. 光反応}

ベンゼンの単分子光反応は異性化反応とベン ゼン環の開裂反応があり, 生成物及びその収量 は励起波長により大きく影響を受ける ${ }^{3)} 。$ 代表 的単分子反応を表 IIに揭げる。

気相 $\mathrm{S}_{3}$ 励起で生成するフルベンは添加気体 $\mathrm{N}_{2}$ ガスの影響を受け, $\mathrm{N}_{2}$ ガスの圧力の増大に 伴って一度増加し次には減少することが50気圧

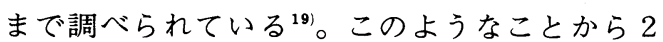
種類の反応中間体が提案されている。これに対 し気相 $\mathrm{S}_{1}$ 励起では添加気体の影響は顕著でな い。242nmでは実質上 $\phi_{f}+\phi_{i s c} \sim 0$ であるが, この付近の励起でも反応収量はやや増大するこ となどから反応は振動励起状態から生じるとさ れている。溶液中の光反応も異性化に関しては 緩和した蛍光状態からの反応でなく振動励起状 態からの反応，又，206nm 励起で生成するデュ ワーベンゼンは $\mathrm{S}_{2}$ 経由の反応とされている。

ナノ秒レーザーフォトリシスによる明確な反 応過程の追跡は今後の課題である。シクロへキ サン溶液にレーザー光を照射して得られた反応 物のスペクトルをFig. 9 に示す。 $270 \mathrm{~nm}$ 以下の

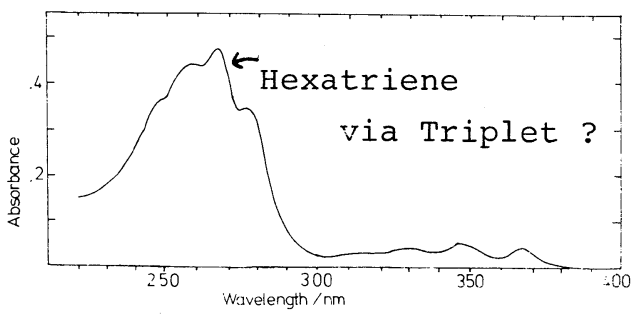

Fig. 9. Photoproducts of benzene in cyclohexane $4.6 \times 10^{-3} \mathrm{M}$ by an excimer laser. Degased solutions $(2 \mathrm{ml})$ were irradiated by 70 shots of a $248 \mathrm{~nm}, 40 \mathrm{~mJ}, 15 \mathrm{~ns}$ pulse.

スペクトルはヘキサトリエンに似ている。気相 では（Fig. 10）は振動励起状態ではなく， $\mathrm{S}_{1}$ 経由の生成物が得られた。ベンゼンの3つの異 性体（円，〕）とは異なるも のであった。同定は今後の課題である。

化学者の研究目的の一つは反応の理解にある。 State-to-State chemistny は簡単な分子につ いて盛んであるが，ベンゼンの反応に関しては 励起状態と反応生成物との関係は電子状態につ いてさえ推定の域を出ない。反応過程の直接測 定が待たれる。それには紫外部でしかも精度の 高いナノ，ピコ秒のフラッシュフォトリシスが 必要となる。 


\section{6。気相と溶液の間}

気相と液相で光反応を含む励起状態の挙動は 既に述べて来たように大きく異る。例えば “第 3 チャンネル” は気相のみの現象であるし, デ ユワーベンゼンの生成は溶液のみで知られてい る。これらの差は溶媒が励起状態の過剩エネル ギーを奪い，“かご”効果で知られるように分 子の動きを押えるためであろう。単純にこのよ うな作用だけならば気相一溶液間は連続である ことが予想される。実際にヨウ素分子の分解反 応, シクロヘプタトリエンのトルエンの異性化 反応では高圧下の反応と溶液間で連続であるこ とが確められている ${ }^{20)}$ 。ベンゼンの励起状態の 挙動はどうであろうか, 今後の問題の一つと考 えられる。

\section{7. 露状物篗の生成 ${ }^{21}$}

光による粒子の生成は1869年 Tyndall による “実験室で青空を作った”研究が最初とされて おり，最近ではオキシダントの研究が多数ある。 レーザーによる粒子の生成としてはセシウムと 水素の系 ${ }^{22)}$ 等数例知られている。気相ベンゼン をエキシマーレーザーで照射しても霧状物質の 生成が認められた。（Fig. 11）。種々の測定か ら粒子の直径は $2 \sim 6 \mu \mathrm{m}, 100 \mathrm{~mJ} / \mathrm{cm}^{2}$ の $\mathrm{KrF}$ 一ザーにより生成する数は $10^{5}$ ケ $/ \mathrm{cm}^{3}$ と求めら れた。レーザー光強度の 2 乗に比例し霧の散乱 は強くなり，酸素がこの生成を容易にする。2 光子励起の光反応はベンゼン環の開裂反応であ ると考えられ，酸化されると蒸気圧が数桁低く

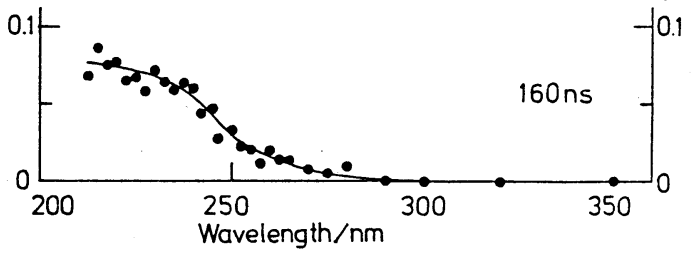

Fig. 10. Transient photoproduct taken at 160 ns after excitation. Mixture of benzene ( 21 Torr) and cis- 2 -butene ( 680 Torr) was irradiated by a $\mathrm{KrF}$ laser. a)

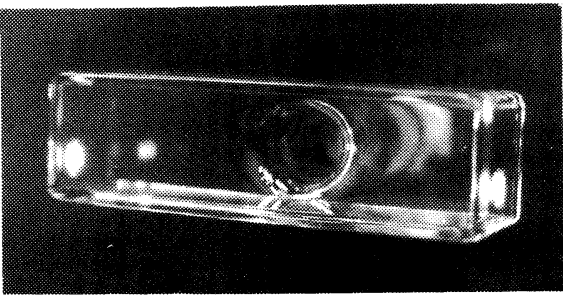

b)

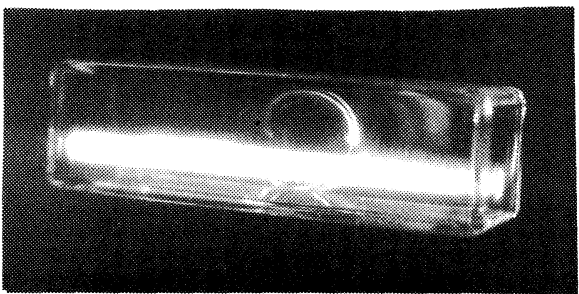

Fig. 11. Mie scattering by particles produced from gaseous benzene excited by a $\mathrm{KrF}$ laser. a) Sample cell before irradiation, b) after irradiation of 40 Torr of benzene and 2 Torr of oxygen. The size of the sample cell is $1.0 \times 1.0 \times 1.0 \mathrm{~cm}^{3}$. The area of the laser beam is $2.5 \times 0.5 \mathrm{~cm}^{2}$. The sample is irradiated without focusing beam.

なることが期待される。この為Nucleation が 起り易くなったと理解される。

\section{8. むすび}

ベンゼンは基本的分子であるから常に最新の 技術を駆使し研究されて来たが，以上述べて来 たように励起状態の緩和過程，気相の三重項状 態, 光反応等で明らかにすべき点が多くある。 エキシマーレーザーという強力な紫外レーザー の利用によりこれらのいくつかは解決されるで あろうし，完全解決には更にパルス幅の短い紫 外光等が必要と思われる。

本稿をまとめるにあたって御意見を頂いた吉 原経太郎教授に感謝致します。

\section{考栲文献}

1 ) 中島, ·吉原 : ナノ・ピコ秒の化学, 化学総説No. 24 , 学会出版センター (1979), p. 83, およびこの本 のいくつかの章に詳しい。 
2 ) C. S. Parmenter, Adv. Chem. Phys., 22 (1972), 365 .

3 ) R. B. Cundall, S. McD. Ogilvie, in Organic Molecular Photophysic, Vol. 2, edited by J. B. Birks (Wiley, New York, 1975), p. 33 ; R. B. Cundall, D. A. Robinson, and L. C. Pereira, in Advances in Photochemistry, Vol. 10, edited dy J. N. Pitts, Jr., G. S. Hammond, and K. Gollnick (Wiley, New York, 1977), p. 147.

4 ) D. Bryce-Smith, A. Gilbert. Tetrahedron, 32 (1976), 1309

5 ) D. Phillips, J. Photochem., 1 (1972/73), 97.

6 ) 馬場 : レーザーと化学反応, 化学総説 No. 26, 学会出版センター $(1980)$, p. 61 , 花崎, 吉原; 同 上, p. 153 .

7 ) M. B. Robin, Higher Excited State of Polyatomic Molecules Vol. 2 (Academic, New York, 1975), p.209.

8 ) N. Nakashima, H. Inoue, M. Sumitani, K. Yoshihara, J. Chem. Phys., 73 (1980), 5976.

$9)$ S. Tagawa, W. Schnabel, Chem. Phys. Lett., 75 (1980), 120.

10) N. J. Turro, M. Aikawa, J. A. Butcher, Jr., IEEE. J. Quantum Electron., Q E-16 (1980), 1218.
11) N. Nakashima, M. Sumitani, I. Ohmine, K. Yoshihara, J. Chem. Phys., 72 (1980), 2226.

12) P. M. Johnson, J. Chem. Phys, 64 (1976), 4143.

13) L. D. Zieglar, B. S. Hudson, Chem. Phys. Lett., 71 (1980), 113.

14) P. Avouris, W. M. Gelbart, M. A. El-Sayed, Chem. Rev. 77 (1977), 793; K. F. Freed, Acc. Chem. Res., 11 (1978), 74.

15）中島, 吉原 : 未発表.

16) C. S. Burton, H. E. Hunziker, Chem. Phys. Lett., 12 (1970), 352; D. Phillips, 私信.

17) T. Ueno, N. Kouchi, S. Takao, Y. Hatano, J. Phys. Chem. 82 (1978), 2373.

18) M. A. Duncan, T. G. Dletz, M. G. Liverman, R. E. Smalley, J. Phys. Chem., 85 (1981), 7.

19) K. Shindo, S. Lipsky, J. Chem. Phys., 45 (1966), 2292.

20) K. Luther J. Troe, Chem. Phys. Lett., 24 (1974), 1 ; S. H. Luu, J. Troe, Ber. Bunsenges. Phys. Chem, 77 (1973), 325,

21）中島, 吉原: 未発表.

22) A. Tam, G. Moe, and W. Happer, Phys. Rev. Lett., 35 (1975), 1630.

23）ピコ秒パルス $(347.2 \mathrm{~nm})$ の 2 光子吸収により, ベンゼンエキシマーに帰属される吸収スペクトルの 測定の報告がある。増原, 浜の上 私信。 